\title{
Investigation of World assumption, personal attributes and gender roles of adolescents
}

\author{
Meral Sert Ağır ${ }^{1, *}$ \\ ${ }^{1}$ Marmara University, Atatürk Faculty of Education, Department of Educational Sciences, \\ Psychological Counseling and Guidance Department, Göztepe Istanbul, Turkey
}

\begin{abstract}
This research aims to examine adolescents' world assumptions, personal attributes and gender roles. The research has attempted to examine the thoughts of adolescents about the world and the ways in which they define themselves as a man or a woman by considering the fact that their lives are affected not only by "traumatic" events but also by several family and environmental dynamics affecting their quality of life. Data was obtained from randomly selected 407 high school students from Kadıköy district in Istanbul province, by applying "World Assumptions Scale (WAS)", "Extended Personal Attributes Questionnaire (EPAQ)", "Gender Roles Attitude Scale (GRAS)", and "Data Collection Form". Our results showed that there was a significant difference in the scales and subdimensions used in the research with respect to gender, grade, family characteristics as well as life standards, balance of standards, adequacy of/change in family income, living with the family without problems, level of satisfaction with the environment, and the desire to change the living environment. In addition to a positive relationship between world assumptions and personal attributes, various correlations in different directions were also found between the sub-dimensions of the scales. Our research has shown that adolescents' life dynamics can make a difference in their perception of the world and their assumptions about perceiving themselves as moral and valuable individuals, as well as their personal attributes and perceptions about gender roles.
\end{abstract}

Keywords: World assumptions, personal attributes, gender roles, quality of life, adolescence, gender identity and sex role behaviors

\section{Introduction}

Each person's reality contains comments about what is happening and what will happen in the shadow of perceptions and schemas that are linked to their experiences and the traces left behind by these experiences [1]. A schema is the knowledge of the human about the world. Schemas are acquired through the mental processes of human beings [2,3]. Human beings perceive the world, define what they perceive, and their definitions bring explanations about the meaning of life. Each of these explanations contains comments that

\footnotetext{
* Corresponding author: meralagir@marmara.edu.tr-meralagir@yahoo.com
} 
carry traces of previous experiences. Therefore, although the building blocks of people are the same, thoughts, feelings and behaviors regarding life are different. This difference is a sign of the understanding and expectation of each person in terms of life [4]. In a sense, human beings manage their lives through definitions and explanations about the world in which they live in and motivate themselves to live. Thus, they adopt a particular attitude by means of thoughts and beliefs that they formed in the face of the changing dynamics of life $[5,6]$.

According to the cognitive theory, human beings fundamentally have positive assumptions about themselves and the world, but their interactions can lead to a change of positive beliefs [7]. In recent years, theoreticians have conceptualized beliefs and thoughts about stressful events that change behavior styles of individuals as "casual attributions", "coping potential" and "meaning". Attribution is positive or negative characteristic explanations formed against encountered events, and coping skills are emotion-oriented and problem-based behavioral strategies. The assumptions are the ideas and beliefs developed based on schemas [8].

According to the Theory of Basic Assumptions, which explains human thoughts and behaviors with cognitive understanding, three basic assumptions define behavior: "benevolence of the world", "meaningfulness of the world" and "perceived benevolence of the world". These assumptions are supported by eight hypotheses [9] (see Table 1).

Table 1. World Assumptions and related hypotheses

\begin{tabular}{|l|l|l|l|}
\hline Assumptions & Benevolence of the world & $\begin{array}{l}\text { Meaningfulness of the } \\
\text { world }\end{array}$ & Worthiness of self \\
\hline Hypotheses & $\begin{array}{l}\text { Benevolence of the world } \\
\text { Benevolence of human beings }\end{array}$ & $\begin{array}{l}\text { Justice } \\
\text { Control } \\
\text { Randomness }\end{array}$ & $\begin{array}{l}\text { Self-worth } \\
\text { Self-control } \\
\text { Luck }\end{array}$ \\
\hline
\end{tabular}

According to the theory, three basic assumptions involving eight hypotheses are based on the schemas that the world we live in is a safer place and not a hurtful place. As they are formed with interactions, these schemas may produce an effort to cope with the challenges related to empowerment and development but may also have the opposite effect. According to the relevant literature, the formation of negative assumptions of humans with "traumatic events", experiences that deeply influence the natural course of life as opposed to anticipation or expectation. In other words, while the innate and positive assumption that the world is a safe and invulnerable (place will be replaced by negative assumptions about "benevolence of the world, meaningfulness of the world, and worthiness of self" after traumatic experiences, it differentiates the style of behaviors as well $[10,11,12,13]$.

As can be seen, the assumptions (beliefs) that arise as a result of past learning can make a difference in terms of meeting life functions.

Human life is the process of learning, change and development including opportunities and challenges. Humans should strive and struggle to gain the competences at each step of the development process and to fulfill the functions of future life. In addition, each step in the progressional process has a critical importance in order to survive in terms of acquiring certain features [14]. Among these, adolescence is a transitional period with critical importance that enables human beings who are dependent from birth due to developmental dynamics to mature into independent individuals. Adolescence is the questioning period where one decides "who s/he will be", i.e. the period where the style of performing life functions/duties is decided upon. In a sense, humans decide what their thoughts about themselves and the world should be during adolescence and how they will meet the functions of following periods of life $[15,16]$. The style of fulfilling "gender identity" and "sex roles" that carry a psychological, sociological and cultural meaning within the context 
of social roles and definitions highlight adolescents' definition of "identity" about themselves. Thus, they distinguish themselves beyond the notions of "men" and "women" of biological origin, by using "masculinity" and "femininity", which correspond to the way of carrying out functions in life [17,18].

The way of coping with the environmental difficulties of the period as well as the developmental difficulties form within the context of adolescent's thoughts on him/herself and life [19]. In the context of cognitive theory, the adolescent's interactions may affect the attributions about the world, the way of meaningfulness, and his/her capacity to cope with problems. In other words, the behavior generated by the assumptions that the world is a safe place where the people are helpful and get what they deserve, can make a difference with their behavior, and they are valuable in this word and protect themselves from evil with correct behaviors will not be the same with the behavior produced by the opposite assumptions [20]. Therefore, adolescents' definition of "identity" about what kind of an adult one will be, and the "masculinity" and "femininity" role behaviors described by the concept of "gender identity" can change [21].

In the light of these theoretical dynamics, "traumatic events" that are effective on world assumptions were analyzed in this research in the context of quality of life [22,23,24,25], based on the literature on the importance of having a life that fits "life standards" for adolescents. The research was conducted in the context of socio-economic factors to explain adolescent's world assumptions and role definitions of gender identity. In this respect, the research aimed to examine adolescents' world assumptions and personal attributions (in terms of gender identity) and sex role behaviors in relation to quality of life standards.

\section{Method}

\subsection{Research Method}

This research examined adolescents' world assumptions, personal attributions and sex roles. The relational screening model was used in the research.

\subsection{Study Group}

Study group consisted of 407 randomly selected students (169 male, 238 female) studying at 9th, 10th, 11th grades in Kadiköy district of İstanbul province in 2015-2016 academic year.

\subsection{Data Collection Tools}

Institutional approval was obtained from İstanbul Governorship Provincial Directorate of Education Number: 59090411-20-E.4529708, Dated:21.04.2016. Data were collected by "World Assumptions Scale" standardized by Y1lmaz [26], "Extended Personal Attributes Questionnaire" standardized by Demirtaş-Mardan [27], "Gender Roles Attitude Scale" developed by Zeyneloğlu [28] and "Personal Information Form" prepared by the researcher. 


\subsection{Data Analysis}

The data were analyzed in SPSS computer program using t test, one-way analysis of variance and relationship techniques. Gender were investigated by $t$ Test, whereas differences with respect to some variables were investigated by one way analysis of variance.

\section{Results}

Results of this research are listed below.

3.1. According to the gender characteristic, a significant difference is found in the random dimension, one of the sub-dimensions of the World Assumptions Scale (WAS), and in the negative and positive masculinity sub-dimensions of Extended Personal Attributes Questionnaire (EPAQ) in favor of men, and in the "equalitarian gender role, female gender role, marriage gender role, traditional gender role, male gender role", in the sub-dimensions of the Gender Roles Attitude Scale (GRAS), in favor of women.

Table 2. $T$ test results of scales and sub-dimensions according to gender variable

\begin{tabular}{|l|c|c|c|c|}
\hline Scales/Subdimensions & $\mathbf{t}$ & $\mathbf{p}$ & $\begin{array}{c}\overline{\mathbf{x}} \\
\text { MALE }\end{array}$ & $\begin{array}{c}\overline{\mathbf{x}} \\
\text { FEMALE }\end{array}$ \\
\hline Randomness & 3.400 & 0.001 & 20.48 & 18.94 \\
\hline Negative masculinity & 2.854 & 0.005 & 16.62 & 15.45 \\
\hline Positive femininity & -2.970 & 0.003 & 27.90 & 29.47 \\
\hline Masculinity-femininity & -4.814 & 0.000 & 24.96 & 27.42 \\
\hline Positive masculinity & 3.547 & 0.000 & 29.75 & 27.57 \\
\hline Negative femininity (verbal) & -4.190 & 0.000 & 10.17 & 11.63 \\
\hline Gender Roles Attitude Scale & -8.416 & 0.000 & 132.82 & 153.08 \\
\hline Equalitarian gender role & -5.203 & 0.000 & 31.31 & 34.77 \\
\hline Female gender role & -5.474 & 0.000 & 24.95 & 28.62 \\
\hline Marriage gender role & -6.857 & 0.000 & 30.86 & 35.05 \\
\hline Traditional gender role & -9.122 & 0.000 & 23.92 & 29.97 \\
\hline Masculine gender role & -5.613 & 0.000 & 21.76 & 24.66 \\
\hline
\end{tabular}

3.2. According to the grade, in the random sub-dimension of WAS a difference is found between 9th and 10th grade students in favor of 9th grade students; between 10th and 11th grade students in favor of 11th grade students; in the marriage gender role sub-dimension of GRAS, a difference is found between 9th and 10th grade students in favor of 10th students.

Table 3. One-way Analysis of Variance (ANOVA) Results of Scales and Sub-Dimensions According to Grade Variable

\begin{tabular}{|l|c|c|}
\hline Grade & F & p \\
\hline Randomness & 5.103 & 0.006 \\
\hline Marriage gender role & 4.919 & 0.008 \\
\hline
\end{tabular}


3.3. According to the mother's education level, in the luck sub-dimension of WAS, a significant difference is found between those whose mothers are graduated from high school and whose mothers are illiterate in favor of high school graduates. There is a significant difference found between those whose mothers are graduated from the university and those whose mothers are illiterate in favor of students whose mothers are university graduates. In the female gender role sub-dimension of the GRAS, a significant difference is found between those whose mothers are graduated from the university and those whose mothers are graduated from elementary school in favor of students whose mothers are university graduates. In the traditional gender role sub-dimension, a significant difference is found between those whose mothers are graduated from high school and those whose mothers are graduated from elementary school in favor of high school graduates. According to the level of father's education, no significant difference is found in the related scales and their sub-dimensions.

Table 4. One-way analysis of variance (Anova) results of scales and sub-dimensions according to mother educational status variable

\begin{tabular}{|l|c|c|}
\hline Mother Educational Status & F & p \\
\hline Luck & 4.380 & 0.002 \\
\hline Gender Roles Attitude Scale & 3.641 & 0.006 \\
\hline Traditional gender role & 3.115 & 0.015 \\
\hline
\end{tabular}

3.4. According to the mother's employment level, in the total scores of GRAS, a significant difference is found between those whose mothers work full time and those whose mothers are housewife in favor of those working full time; in terms of female gender role, a significant difference is found between those whose mothers work full time and those whose mothers are housewife in favor of those working full time, and between those whose mothers are retired and those whose mothers are housewife in favor of those retired.

Table 5. One-way analysis of variance (Anova) results of scales and sub-dimensions according to mother's employment level variable

\begin{tabular}{|l|c|c|}
\hline Mother's Employment Level & F & p \\
\hline Gender Roles Attitude Scale & 3.808 & 0.010 \\
\hline Female gender role & 8.686 & 0.000 \\
\hline
\end{tabular}

3.5 According to father's working level, in the justice sub-dimension of WAS, a significant difference is found among those whose fathers are retired, those whose fathers work full time and those whose fathers work half-time in favor of those retired; in the negative masculine sub-dimension of the EPAQ, a significant difference is found between those whose fathers work half-time and those whose fathers work full-time in favor of those working half-time.

Table 6. One-way analysis of variance (Anova) results of scales and sub-dimensions according to father's employment level variable

\begin{tabular}{|l|c|c|}
\hline Father's Employment Level & F & p \\
\hline Justice & 3.437 & 0.017 \\
\hline Negative masculinity & 3.128 & 0.026 \\
\hline
\end{tabular}

3.6. In the WAS and its sub-dimensions justice, luck, self-worth, according to the situation of a crisis related to the income of the family (dismissal of the family member, income drop) experienced in the last 5 years, a significant difference is found in favor of those who haven't had a crisis. In the negative masculine sub-dimension of the EPAQ, 
female gender role and traditional gender role sub-dimensions of GRAS, there is a significant difference in favor of those who have had a crisis.

Table 7. $T$ test results of scales and sub-dimensions according to crises in the family variable

\begin{tabular}{|l|c|c|c|c|}
\hline $\begin{array}{l}\text { The situation of a crisis related to the income of } \\
\text { the family experienced in the last 5 years }\end{array}$ & $\mathbf{t}$ & $\mathbf{p}$ & $\begin{array}{c}\overline{\mathbf{x}} \\
\text { (Yes) }\end{array}$ & $\begin{array}{c}\overline{\mathbf{x}} \\
\text { (No) }\end{array}$ \\
\hline World Assumptions Scale & -2.807 & 0.005 & 106.96 & 113.35 \\
\hline Justice & -2.540 & 0.011 & 17.98 & 20.18 \\
\hline Luck & -2.204 & 0.028 & 14.67 & 16.16 \\
\hline Self-worth & -2.743 & 0.006 & 15.43 & 16.95 \\
\hline Negative masculinity & 2.248 & 0.025 & 16.85 & 15.71 \\
\hline Gender Roles Attitude Scale & 2.025 & 0.044 & 149.86 & 143.37 \\
\hline Female gender role & 3.100 & 0.002 & 29.20 & 26.57 \\
\hline Traditional gender role & 1.996 & 0.047 & 28.89 & 27.10 \\
\hline
\end{tabular}

3.7 In the relevant WAS and its sub-dimension of justice, according to whether there has been an increase in family income over the last 5 years, there is a significant difference found in favor of those that had an increase. In the negative femininity (relational) subdimension of the EPAQ and the female gender role and traditional gender role subdimensions of GRAS, a significant difference is found in favor of those that does not have an increase.

Table 8. T test results of scales and sub-dimensions according to increase in family income over the last 5 years variable

\begin{tabular}{|l|c|c|c|c|}
\hline Increase in family income over the last 5 years & $\mathbf{t}$ & $\mathbf{p}$ & $\begin{array}{c}\overline{\mathrm{X}} \\
\text { (Yes) }\end{array}$ & $\begin{array}{c}\overline{\mathrm{x}} \\
\text { (No) }\end{array}$ \\
\hline World Assumptions Scale & 2.397 & 0.017 & 114.37 & 110.00 \\
\hline Justice & 2.175 & 0.030 & 20.53 & 19.02 \\
\hline Negative femininity (relational) & -2.052 & 0.041 & 9.24 & 9.86 \\
\hline Gender Roles Attitude Scale & -2.341 & 0.020 & 26.26 & 27.85 \\
\hline Traditional gender role & -2.154 & 0.032 & 26.65 & 28.19 \\
\hline
\end{tabular}

3.8. In the WAS, according to the situation of thinking that you are living without economic difficulties with your family, a significant difference is found between those who have given the answer always and sometimes in favor of those who say always. In favor of those who say frequently between those who have given the answer frequently and sometimes; and in the justice, luck and control sub-dimensions, there is a significant difference found in favor of those who say always between those who have given the answer always and sometimes; in the self-worth sub-dimension a significant difference is found in favor of those who say always among those who have given the answer always and sometimes and never; in the positive masculine sub-dimension of the EPAQ, a significant difference is found in favor of those who say always among those who have given the answer always and never; in favor of those who say frequently between those who have given the answer frequently and never; in the negative femininity (relational) sub-dimension, there is a significant difference found in favor of those who say always among those who have given the answer always and sometimes. 
Table 9. One-way analysis of variance (Anova) results of scales and sub-dimensions according to the situation of thinking that living without economic difficulties with your family variable

\begin{tabular}{|l|c|c|}
\hline $\begin{array}{l}\text { The situation of thinking that you are living without economic } \\
\text { difficulties with your family }\end{array}$ & F & p \\
\hline World Assumptions Scale & 9.098 & 0.000 \\
\hline Justice & 4.083 & 0.003 \\
\hline Luck & 4.072 & 0.003 \\
\hline Self-worth & 8.891 & 0.000 \\
\hline Control & 4.501 & 0.001 \\
\hline Positive masculinity & 3.307 & 0.011 \\
\hline
\end{tabular}

3.9. In the WAS according to the situation of whether being satisfied with the district /living area, there is a significant difference found between those who have given the answer always and never in favor of those who say always; between those who have given the answer frequently and never in favor of those who say frequently; and between those who have given the answer sometimes and never in favor of those who say sometimes; in the sub-dimensions justice, benevolence, self-worth, control, there is a significant difference found between those who have given the answer always and never in favor of those who say always. In the positive femininity sub-dimensions of EPAQ, there is a significant difference found between those who have given the answer always and never in favor of those who say always; regarding the GRAS total score, a significant difference is found in favor of those who say never among those who have given the answer never and always; in the dimensions of female gender role and marriage gender role, there is a significant difference found in favor of those who say never among those who have given the answer never, always and frequently; in the sub-dimensions traditional gender role and male gender role, there is a significant difference found in favor of those who say sometimes among those who have given the answer sometimes and always.

Table 10. One-way analysis of variance (Anova) results of scales and sub-dimensions according to the situation of whether being satisfied with the district /living area variable

\begin{tabular}{|l|c|c|}
\hline The Situation of Whether Being Satisfied With the District/Living & F & p \\
\hline World Assumptions Scale & 9.051 & 0.000 \\
\hline Justice & 8.782 & 0.000 \\
\hline Benevolence & 2.720 & 0.029 \\
\hline Self-worth & 7.581 & 0.000 \\
\hline Control & 2.799 & 0.026 \\
\hline Positive femininity & 2.985 & 0.019 \\
\hline Gender Roles Attitude Scale & 3.322 & 0.011 \\
\hline Female gender role & 3.515 & 0.008 \\
\hline Marriage gender role & 3.374 & 0.010 \\
\hline Traditional gender role & 3.018 & 0.018 \\
\hline Masculine gender role & 2.409 & 0.049 \\
\hline
\end{tabular}

3.10. In the WAS and justice sub-dimension, according to the situation of desiring to change the environment they are in, there is a significant difference found between those who have given the answer never and always in favor of those who say never; in the dimension of luck, between those who say never and frequently in favor of those who say never; in the dimension self-worth, between those who say sometimes and always in favor of those who say sometimes and between those who say rarely and always in favor of those who say rarely; in the traditional gender role sub-dimension of GRAS, there is a significant 
difference found between those who say never and sometimes in favor of those who say never.

Table 11. One-way analysis of variance (Anova) results of scales and sub-dimensions according to the situation of desiring to change the environment they are in variable

\begin{tabular}{|l|c|c|}
\hline The situation of desiring to change the environment they are in & F & p \\
\hline World Assumptions Scale & 5.770 & 0.000 \\
\hline Justice & 5.791 & 0.000 \\
\hline Luck & 3.693 & 0.006 \\
\hline Self worth & 6.366 & 0.000 \\
\hline Traditional gender role & 2.401 & 0.049 \\
\hline
\end{tabular}

3.11. In the WAS and its sub-dimensions justice, benevolence, self-worth, according to the situation of thinking a positive change will occur in their lives within 5 years, there is a significant difference found in favor those who say yes and in the negative masculine subdimension of EPAQ, in favor of those who say no; in the equalitarian gender role subdimension of GRAS, there is a significant difference found in favor those who say yes.

Table 12. $T$ test results of scales and sub-dimensions according to the situation of thinking a positive change will occur in their lives within 5 years variable

\begin{tabular}{|l|c|c|c|c|}
\hline $\begin{array}{l}\text { The situation of thinking a positive change will } \\
\text { occur in their lives within 5 years }\end{array}$ & $\mathbf{t}$ & $\mathbf{p}$ & $\begin{array}{c}\overline{\mathbf{x}} \\
\text { (Yes) }\end{array}$ & $\begin{array}{c}\overline{\mathbf{x}} \\
\text { (No) }\end{array}$ \\
\hline World Assumptions Scale & 3.901 & 0.000 & 113.44 & 103.00 \\
\hline Justice & 2.023 & 0.044 & 20.01 & 17.92 \\
\hline Benevolence & 3.432 & 0.001 & 31.46 & 27.72 \\
\hline Self-worth & 3.399 & 0.001 & 16.94 & 14.72 \\
\hline Negative masculinity & -2.865 & 0.004 & 15.71 & 17.43 \\
\hline Equalitarian gender role & 2.144 & 0.033 & 33.62 & 31.47 \\
\hline
\end{tabular}

3.12. In the EPAQ sub-dimension positive femininity, in the GRAS and its subdimensions equalitarian gender role, marriage gender role and male gender role; according to the situation of thinking a positive change will occur in their lives within 5 years with the education received, there is a significant difference found in favor of those who say yes.

Table 13. $T$ test results of scales and sub-dimensions according to the situation of thinking a positive change will occur in their lives within 5 years with the education received variable

\begin{tabular}{|l|r|r|r|r|}
\hline $\begin{array}{l}\text { The situation of thinking a positive change will } \\
\text { occur in their lives within 5 years with the education } \\
\text { received }\end{array}$ & $\mathbf{t}$ & $\mathbf{p}$ & \multicolumn{1}{|c|}{$\begin{array}{c}\overline{\mathbf{x}} \\
\text { (Yes) }\end{array}$} & \multicolumn{1}{|c|}{$\begin{array}{c}\overline{\mathrm{x}} \\
\text { (No) }\end{array}$} \\
\hline Positive femininity & 2,414 & 0,016 & 29,07 & 27,20 \\
\hline Gender Roles Attitude Scale & 2,566 & 0,011 & 145,95 & 136,30 \\
\hline Equalitarian gender role & 3,056 & 0,002 & 33,74 & 30,72 \\
\hline Marriage gender role & 2,082 & 0,038 & 33,57 & 31,63 \\
\hline Masculine gender role & 2,107 & 0,039 & 23,71 & 21,85 \\
\hline
\end{tabular}

3.13. In the positive femininity, one of the EPAQ sub-dimensions, and female gender role and traditional gender role sub-dimensions of GRAS; according to the situation that additional training should be taken to change/improve life, there is a significant difference found in favor of those who say yes. 
Table14. $T$ test results of scales and sub-dimensions according to the situation that additional training should be taken to change/improve life variable

\begin{tabular}{|c|c|c|c|c|}
\hline $\begin{array}{l}\text { The situation that additional training should be } \\
\text { taken to change/improve life }\end{array}$ & $\mathbf{t}$ & $\mathbf{p}$ & $\begin{array}{c}\overline{\mathrm{x}} \\
(\text { Yes })\end{array}$ & $\begin{array}{c}\overline{\mathrm{X}} \\
(\mathbf{N o})\end{array}$ \\
\hline Positive femininity & 2.207 & 0.028 & 29.15 & 27.83 \\
\hline Gender Roles Attitude Scale & 2.195 & 0.029 & 146.30 & 139.84 \\
\hline Female gender role & 2.750 & 0.006 & 27.64 & 25.50 \\
\hline Traditional gender role & 2.016 & 0.044 & 27.88 & 26.22 \\
\hline
\end{tabular}

3.14. As a result of correlation analyses, positive correlation $(\mathrm{r}=0.116)$ was observed between WAS and EPAQ, moreover, it is observed that there are positive and negative relationships among the sub-dimensions of the features of the research topic.

Table 15. Correlation table between the scales

\begin{tabular}{|c|c|c|c|c|}
\hline & & $\begin{array}{c}\text { World } \\
\text { Assumptions } \\
\text { Scale }\end{array}$ & $\begin{array}{l}\text { Extended } \\
\text { personal } \\
\text { attributes }\end{array}$ & $\begin{array}{l}\text { Gender Roles } \\
\text { Attitude Scale }\end{array}$ \\
\hline \multirow{3}{*}{$\begin{array}{l}\text { World } \\
\text { Assumptions } \\
\text { Scale }\end{array}$} & Pearson Correlation & 1 & $.116^{*}$ & -.057 \\
\hline & Sig. (2-tailed) & & .020 & .252 \\
\hline & $\mathrm{N}$ & 407 & 407 & 407 \\
\hline \multirow{3}{*}{$\begin{array}{l}\text { Extended } \\
\text { personal } \\
\text { attributes }\end{array}$} & Pearson Correlation & $.116^{*}$ & 1 &,- 015 \\
\hline & Sig. (2-tailed) &, 020 & & .762 \\
\hline & $\mathrm{N}$ & 407 & 407 & 407 \\
\hline \multirow{3}{*}{$\begin{array}{l}\text { Gender Roles } \\
\text { Attitude Scale }\end{array}$} & Pearson Correlation & -.057 & -.015 & 1 \\
\hline & Sig. (2-tailed) & .252 & .762 & \\
\hline & $\mathrm{N}$ & 407 & 407 & 407 \\
\hline
\end{tabular}

\section{Discussion}

4.1. In the random sub-dimension of the world assumptions questionnaire (WAS), according to gender feature difference is found in favor of boys (Male $\bar{x}=20.48$; Female $\bar{x}=18.94$ ). Depending on the proposition of "justice, controllability and random" of the meaningfulness of world assumption of the relevant scale, it involves thoughts about how much people can get or deserve according to various criteria (according to the individual's schema). As a requirement of the just world, it emphasizes that everybody can get what they deserve as well as the link between behavior and outcomes [29]. Coincidence in this dimension explains that the events have a natural course and that making effort is meaningless, vain behavior. In this dimension, the difference in favor of boys suggests that boys believe that the effort to change their lives is meaningless. In the negative masculinity sub-dimension of the Extended Personal Attributes Questionnaire (EPAQ) (Male $\bar{x}=16.62$; Female $\bar{x}=15.45$ ) and in the positive masculinity (Male $\bar{x}=29.75$; Female $\bar{x}=27.57$ ) sub-dimension, there is a significant difference found in favor of boys; in the masculinity-femininity (Male $\bar{x}=24.96$ ); Female $\bar{x}=27.42$ ), positive femininity (Male $\bar{x}=27.90$; Female $\bar{x}=29.47$ ), negative femininity (verbal) (Male $\bar{x}=10.17$; Female $\bar{x}=11.63$ ) sub-dimensions, there is a significant difference found in favor of girls. The negative masculinity dimension corresponds to the negative role behaviors such as arrogance, selfishness, dictatorship, hostility whereas the positive masculinity dimension corresponds to the positive role behaviors such as ambition, independence, being active, competitiveness, easy decision making, self-confidence, pressure resistance. In 
terms of these characteristics, boys getting higher scores than girls show positive gender identity behaviors on the one hand and their inclination to the negative identity behaviors on the other hand. Considering that the average of random dimension is higher in boys' assumptions about the world, it is thought that their assumptions about life is negative and that their negative masculine behavior tendencies as gender identity behaviors are consistent with this knowledge. That the average of girls in masculinity femininity is higher than boys in the sub-dimensions of the EPAQ, is consistent with the finding obtained from the standardization study of the scale. This dimension includes both positive and negative features of the masculine and femininity traits; for example, dominant, liking to serve others, materialist, easily feeling panic in the moment of a crisis, aggressive; and the positive femininity qualities of girls corresponding to qualities such as emotional, being able to dedicate oneself to others, polite, helpful, understanding, sincere. In addition to the fact that the positive femininity point averages of girls are high, the difference among the average scores of negative female (verbal) characteristics (grouchy, constantly whining, grumbler, elaborative, choosy) is consistent with the literature as in boys [31]. In the studies on gender identity, as a human being, neither "female" nor "male" has pure positive or negative characteristics.

Gender Roles Attitude Scale (GRAS) total point averages (Male $\bar{x}=132.82$; Female $\bar{x}=153,08)$ and there has been a difference in favor of females in the sub-dimension of "equalitarian gender role (Male $\bar{x}=31.31$; Female $\bar{x}=34,77$ ), female gender role (Male $\bar{x}=24.95$; Female $\bar{x}=28.62$ ), marriage gender role (Male $\bar{x}=30.86$; Female $\bar{x}=35.05$ ), traditional gender role (Male $\bar{x}=23,92$; Female $\bar{x}=29,97$ ), male gender role (Male $\bar{x}=23.92$; Female $\bar{x}=29.97$ )". It is supported by the data regarding socio-cultural dynamics that girls participating in the research differ from the relevant sub-dimensions of the relevant boys in gender roles [32].

4.2. In the sub-dimension of "random" sub-dimension of the WAS, according to the grades, there is a difference found in the score averages of 9th grades $(\bar{x}=19.89)$ from 10th grades $(\bar{x}=18.39), 11$ th grades $(\bar{x}=20.15)$. This finding suggests that students differ in the way they make sense of the world depending on the class level. In the GRAS subdimension "marriage gender role", there is a difference found in favor of 10th grade between the scores of 10th grade $(\bar{x}=34.95)$ and 9th grade $\bar{x}=32.60)$. It is observed that there is a difference in the way of 10th grade students' perception regarding male and female roles within the marriage institution defined by the society.

4.3. According to the mother's education level, there is a significant difference found in the WAS total scores in favor of high school graduates between those whose mothers are graduated from high school $(\bar{x}=112.90)$ and whose mothers are illiterate $(\bar{x}=98.11)$; there is a significant difference found in favor of university graduates between those whose mothers are graduated from university $(\bar{x}=115.03)$ and those whose mothers are illiterate $(\bar{x}=98.11)$. The difference in this dimension shows that the educational level of the mother can make a difference in their positive thoughts and beliefs in their assumptions about the world. In the "luck" sub-dimension of WAS, according to the education level of the mother, there is a significant difference found in favor of university graduates between those whose mothers are graduated from university $(\bar{x}=16.98)$ and those whose mothers are graduated from secondary school $(\bar{x}=14.20)$. The difference in this dimension can work according to the improbability principle in the context of random proposition of the assumption of meaningfulness of the world, however the individual has the belief that he can protect himself from bad luck. Therefore, according to the sub-proposal of the self-worth assumption of the mother's education level, it is possible to say that the belief that they can protect themselves from bad luck can make a difference and this result is consistent with the previous finding about the level of education of the mother. In the "female gender role" sub-dimension of GRAS, there is a significant difference found between those whose 
mothers are graduated from university $(\bar{x}=28.49)$ and those whose mothers are graduated from elementary school $(\bar{x}=25.25)$ in favor of university graduates. In the "traditional gender role" sub-dimension of GRAS, there is a significant difference found between those whose mothers are graduated from high school $(\bar{x}=28.76)$ and those whose mothers are graduated from elementary school $(\bar{x}=25.79)$ in favor of high school graduates. Both findings of the relevant scale show that the level of education of their mother can make a difference on student's perceptions of female gender role and traditional gender role [32].

4.4. According to mother's working status, in the total GRAS scores, there is a significant difference found between those whose mothers work full-time $(\bar{x}=150.21)$ and those whose mothers are housewife $(\bar{x}=142.19)$ in favor of those working full-time. According to mother's working status, the female gender role sub-dimension of GRAS, there is a significant difference between those whose mothers work full-time $(\bar{x}=29.56)$ and those whose mothers are housewife $(\bar{x}=26.03)$ in favor of those whose mothers work full time and there is a significant difference between those whose mothers are retired $(\bar{x}=31.20)$ and those whose mothers are housewife $(\bar{x}=26.03)$ in favor of those whose mothers are retired. It shows that the mother is working or has worked can change the perception regarding the communal gender roles. This finding is in line with findings on the level of maternal education and is supported by the literature on studies related to gender equality $[34,35,36]$.

4.5. According to the father's working level, in the justice sub-dimension of WAS, there is a significant difference found between those who have retired fathers $(\bar{x}=22.40)$, those who have fathers working full-time $(\bar{x}=19.56)$ and those who have fathers working halftime, $(\bar{x}=17.18)$. The difference in justice dimension is based on the belief that the world has a fair order that provides results that are appropriate for everyone's behavior regarding the assumptions about the world. The difference of the scores of those whose fathers have retired shows that these students have significant thoughts about world being a fair place, in other words everyone can get results in the direction of their effort [37]. Considering that retirement period is a dynamic related to the performance that the individual has shown in his or her working life, it is thought that finding gives information about the difference of the assumptions on world of the students whose fathers are still working, the effect of socioeconomic dynamics on young people. In the negative masculine sub-dimension of EPAQ, there is a significant difference found between those whose fathers work half-time $(\bar{x}=30.18)$ and those whose fathers work full-time $(\bar{x}=28.29)$. It is seen that negative male role behaviors such as selfishness, hostility and dictatorship are role models in the definition of male gender role in those whose fathers work half-time. It is thought that this situation is related to the psychological dynamics that father working half-time can create on the relationship with himself and his immediate environment as "an individual". This finding is in favor with those whose fathers are retired and consistent with the finding related to the justice sub-dimension of the WAS. The difference that is created by the working status of the father both in the WAS and EPAQ sub-dimensions can be supported by the findings of interdisciplinary studies [38,39].

4.6. According to whether a crisis had been faced related to the income of the family (dismissal of a family member, loss of income) in the last five years, there is a significant difference in WAS total scores and justice, luck and self-worth sub-dimensions of WAS in favor of those who did not experience a crisis [40]. This finding shows those who did not face an economic crisis have positive beliefs concerning "benevolence of the world, meaningfulness of the world". There is a significant difference between the negative masculine sub-dimension of EPAQ, the female gender role and traditional gender role subdimensions of GRAS and GRAS in favor of those who did not experience a crisis. This finding shows facing a crisis is one of the factors that affect negative masculine behavior. Similarly, it can be said that the effects of experiencing a crisis on female gender role and 
traditional gender role differ. Accordingly, experiencing an economic crisis can change the student's perception of the world that it will be safe and invulnerable, as well as in the gender identity perception and role specifications.

4.7. According to an increase in the income of the family in the last five years, there is a significant difference found in WAS ( $\mathrm{Y} \bar{x}=114.37 ; \mathrm{N} \bar{x}=110.00)$ and in the justice subdimension of WAS ( $\mathrm{Y} \bar{x}=20.53 ; \mathrm{N} \bar{x}=19.02)$ in favor of those who have an increase (who responded yes). This difference shows, it can be effective in developing positive thoughts in respect of the world being safe and them not being vulnerable. There is a significant difference found in negative femininity (relational) sub-dimension of EPAQ (Y $\bar{x}=9.24$; $\mathrm{N} \bar{x}=9.86$ ), female gender role sub-dimension of GRAS ( $\mathrm{Y} \bar{x}=26.26 ; \mathrm{N} \bar{x}=27.85)$ and the traditional gender role sub-dimension ( $\mathrm{Y} \bar{x}=26.65$; $\mathrm{N} \bar{x}=28.19)$ in favor of those who did not have an increase (who responded no). The result acquired with the aspect of WAS and justice sub-dimension in favor of those who have an increase in income within the last five years, and the results related to whether having a crisis in the family income or not in within the last five years support each other. The differentiation of the condition of not having an increase in income with regards to negative femininity (relational) sub-dimension of EPAQ, female gender role sub-dimension of GRAS and the traditional gender role emphasizes the importance of social roles and expectations attributed to women concerning economic changes. In addition, interdisciplinary studies on the subject, research on gender equality and domestic violence support this result as well.

4.8. According to living with one's family without having financial difficulties, there is a significant difference found between those who have given the answer always and sometimes in favor of those who say always in WAS and its sub-dimensions justice, luck, control and self-worth.

(WAS $\bar{x}=116.92 / \bar{x}=102.26$; Justice $\bar{x}=20.94 / \bar{x}=17.02$; Luck $\bar{x}=16.89 / \bar{x}=13.94$; Control $\bar{x}=11.81 / \bar{x}=10.09$; Self-worth $\bar{x}=17.63 / \bar{x}=14.37 /$ Never $\bar{x}=13.53$ ). In addition. there is a significant difference found between those who have given the answer frequently $(\bar{x}=16.82)$. sometimes $(\bar{x}=14.37)$ and never $(\bar{x}=13,53)$ in favor of those who say frequently in self-worth sub-dimension. According to living with one's family without having financial difficulties, the difference in WAS and its sub-dimensions justice, luck, control and self-worth in favor of those who say always, shows that the perception regarding not having any financial difficulties can make a difference in the world assumptions.

According to living with one's family without having financial difficulties, there is a significant difference found between those who have given the answer always $(\bar{x}=29.12)$ and never $(\bar{x}=24.79)$ in favor of those who say always, and between those who have given the answer frequently $(\bar{x}=28.86)$ and never $(\bar{x}=24.79)$ in favor of those who say never in positive masculine sub-dimension of EPAQ. The finding draws attention to the perception regarding the function of the male gender related to family welfare, considering the positive masculine sub-dimension of EPAQ in favor of those who say always; and frequently in the positive masculine sub-dimension. Positive masculine features contain ambition, independence, being active, competitiveness, easy decision making, not giving up, selfconfidence, pressure resistance and superior self-perception. Therefore, it is possible to say that, in terms of sustaining the prosperity of the family, the students care about the mentioned features.

According to living with one's family without having financial difficulties, there is a significant difference found between those who have given the answer sometimes $(\bar{x}=10.43)$ and always $(\bar{x}=9.14)$ in favor of those who say sometimes in negative femininity sub-dimension of EPAQ. It is thought that the result obtained in favor of those who say sometimes in the EPAQ negative femininity (relational) sub-dimension can be evaluated with the features of respective sub-dimension and having these features in terms of the society. According to the respective sub-dimension, the woman is an unscrupulous, flaccid, 
self-deprecating, self-derogatory, gullible, easily-tricked individual. Since an individual with these features is not expected to be able to use family's resources effectively, this person will also be considered responsible. While afore said result draws attention to the perception of "women" roles and duties when the family's financial prosperity can be sustained, it is necessary to consider that the young ones grow with the values of the society they are in. Moreover, studies related to family and women as well as socio-psychological research support the result $[41,42]$.

4.9. There is a significant difference found between those who have given the answer always $(\bar{x}=116.93)$ and never $(\bar{x}=99.60)$ in favor of those who say always; between those who have given the answer frequently $(\bar{x}=112.41)$ and never $(\bar{x}=99.60)$ in favor of those who say frequently, and between those who have given the answer sometimes $(\bar{x}=111.00)$ and never $(\bar{x}=99.60)$ in favor of those who say sometimes among WAS total scores according to the satisfaction condition of neighborhood / living environment.

There is a significant difference found between those who have given the answer always $(\bar{x}=21.53)$ and never $(\bar{x}=15.14)$ in favor of those who say always; between those who have given the answer frequently $(\bar{x}=19.86)$ and never $(\bar{x}=15.14)$ in favor of those who say frequently and between sometimes $(\bar{x}=19.83)$ and never $(\bar{x}=15.14)$ in favor of those who say sometimes among justice scores, sub-dimension of WAS according to the satisfaction condition of neighborhood / living environment.

There is a significant difference found between those who have given the answer always $(\bar{x}=32.20)$ and never $(\bar{x}=28.42)$ in favor of those who say always in benevolence of people scores, sub-dimension of WAS according to the satisfaction condition of neighborhood / living environment.

There is a significant difference found between those who have given the answer always $(\bar{x}=17.58)$ and never $(\bar{x}=13.80)$ in favor of those who say always and between those who have given the answer frequently $(\bar{x}=17.08)$ and never $(\bar{x}=13.80)$ in favor of those who say frequently among self-worth scores, sub-dimension of WAS according to the satisfaction condition of neighborhood / living environment.

There is a significant difference found between those who have given the answer always $(\bar{x}=11.77)$ and never $(\bar{x}=10.44)$ in favor of those who say always in control scores, a subdimension of WAS according to the satisfaction condition of neighborhood / living environment.

The variation comprising in favor of the students stating, they are always pleased according to the satisfaction characteristics of neighborhood / living environment shows that being satisfied with the social-cultural-economic environment that is being lived in can make difference in the meaningfulness of the world, benevolence of the world and the selfworth among WAS scale total scores in terms of the satisfaction condition of neighborhood / living environment and sub-dimensions of justice, benevolence of people, self-worth and control. In this context, the features of the socio-economic-cultural environment that is being lived in support the faith in the benevolence of people, charity and being courteous while the assumption of justice supports the belief that everyone will acquire the consequences of their behavior in a just world order, In addition, concerning the self-worth, the result related to the students who state that they are always satisfied with the environment they live in, shows that they see themselves as moral, well-behaved and valuable, and that their self-perceptions are positive. A similar result for the control subdimension indicates that students' beliefs about behaviors that can control the outcomes with appropriate acts can be affected by the level of satisfaction with the environment in which they live.

There is a significant difference between those who have given the answer always $(\bar{x}=29.52)$ and never $(\bar{x}=27.24)$ in favor of those who say always among positive femininity scores, sub-dimension of EPAQ according to the satisfaction condition of neighborhood 
/living environment. The results acquired show that the environment can create evaluation regarding the socio-economic conditions and variation of perception concerning the role of women.

There is a significant difference found between those who have given the answer never $(\bar{x}=154.14)$ and always $(\bar{x}=140.99)$ in favor of those who say never among GRAS total scores according to the satisfaction condition of neighborhood / living environment.

There is a significant difference between those who have given the answer never $(\bar{x}=30.22)$, always $(\bar{x}=26.34)$ and frequently $(\bar{x}=26.33)$ in favor of those who say never among female gender role scores, sub-dimension of GRAS according to the satisfaction condition of neighborhood / living environment.

There is a significant difference between those who have given the answer never $(\bar{x}=35.58)$, always $(\bar{x}=32.50)$ frequently $(\bar{x}=32.56)$ in favor of those who say never among marriage gender role scores, sub-dimension of GRAS according to the satisfaction condition of neighborhood / living environment.

There is a significant difference between those who have given the answer sometimes $(\bar{x}=29.26)$ and always $(\bar{x}=26.41)$ in favor of those who say sometimes among traditional gender role scores, sub-dimension of GRAS according to the satisfaction condition of neighborhood / living environment.

There is a significant difference between those who have given the answer sometimes $(\bar{x}=24.20)$ and always $(\bar{x}=22.65)$ in favor sometimes and never $(\bar{x}=24.98)$ and always $(\bar{x}=22.65)$ in favor of those who say never among male gender role scores, sub-dimension of GRAS according to the satisfaction condition of neighborhood / living environment.

GRAS scale and its sub-dimensions of female gender role, marriage gender role, traditional gender role and masculine gender role and their results, variation emerging in terms of low level of satisfaction or no satisfaction condition regarding the living environment shows that the students evaluate the characteristics of the socio-economic cultural environment which they live in from the point of functions related to role and roles. 4.10. There is a significant difference between those who have given the answer never $(\bar{x}=117.79)$ and always $(\bar{x}=107.11)$ in favor of those who say never among WAS total scores according to the situation of desiring to change the environment they are in.

There is a significant difference between those who have given the answer never $(\bar{x}=21.89)$ and always $(\bar{x}=17.69)$ in favor of those who say never among justice scores, subdimension of WAS according to the situation of desiring to change the environment they are in.

There is a significant difference between those who have given the answer never $(\bar{x}=17.04)$ and frequently $(\bar{x}=14.51)$ in favor never, and between those who have given the answer rarely $(\bar{x}=17.40)$ and frequently (14.51) in favor of those who say rarely among luck scores, sub-dimension of WAS according to the situation of desiring to change the environment they are in.

There is a significant difference between those who have given the answer sometimes $(\bar{x}=17.81)$ and always $(\bar{x}=15.32)$ in favor of those who say sometimes, and between those who have given the answer rarely $(\bar{x}=18.12)$ and always $(\bar{x}=15.32)$ in favor of those who say rarely among self-worth scores, sub-dimension of WAS in terms of the condition demanding to change the living environment if possible. Among the total WAS scores according to the situation of desiring to change the environment they are in. According to the situation of desiring to change the environment they are in, WAS total scores, and its sub-dimensions of justice and luck, the result that is obtained supports the variation in favor of the students who stated that they never want to change the environment they live in. Students who think that they do not want to change the environment they live in have positive perceptions about the world being safe and will not allow them to get in a vulnerable situation. The justice dimension states the assumption of the students living in a 
fair world in relation to the distribution of the consequences of their behaviors and the luck dimension states the assumption of them having the luck to protect themselves from evil. Accordingly, it can be said that the students who do not consider changing the environment they live in, have the assumption that appropriate behaviors can ensure this circumstance and that they are the ones who can be protected from evil generated by the coincidences. The result of self-worth sub-dimension of the WAS with regards to those who consider changing the environment they live in and those who rarely think, between those who have given the answer rarely and always, the difference according to those who have given the answer rarely, the individuals who think to change the environment they live in have low self-perception and self-esteem.

There is a significant difference found between those who have given the answer never $(\bar{x}=25.33)$ and sometimes $(\bar{x}=28.73)$ in favor of those who say never among traditional gender role scores, sub-dimension of GRAS. The result obtained from the GRAS perspective suggests that the traditional gender role behaviors of those who have given the answer never differ in the sense of traditional gender role. Therefore, it is possible to say that the traditional gender role definitions of those who do not want to change the environment they live in differ from the egalitarian gender role definitions of the other group.

4.11. According to thinking whether or not a positive change will occur in their lives over the next five years, there is significant difference in the total WAS scores ( $\mathrm{Y} \bar{x}=113.44$ / $\mathrm{N} \bar{x}=103.00)$, sub-dimensions of WAS justice score ( $\mathrm{Y} \bar{x}=20.01 / \mathrm{N} \bar{x}=17.92)$, benevolence of the world score ( $\mathrm{Y} \bar{x}=31.46 / \mathrm{N} \bar{x}=27.72)$, self-worth score $(\mathrm{Y} \bar{x}=16,94 / \mathrm{N} \bar{x}=14,72)$, in the equalitarian gender role sub-dimension of GRAS ( $\mathrm{Y} \bar{x}=33.62$ / N $\bar{x}=31.47)$, in favor of those who think there will be a positive change, and in the negative masculine sub-dimension of EPAQ ( $\mathrm{Y} \bar{x}=15.71 / \mathrm{N} \bar{x}=17.43)$ there is significant difference found in favor of those who do not think that there will be a positive change. The difference in favor of the students who think there will be a positive change in their lives; in WAS total score and its subdimensions justice, benevolence, self-worth; reveal that there are positive thoughts about the benevolence of the world, the significance of the world, and the assumptions of selfworth. In other words, the world is a safe place with features that can meet the expectations of the students and will not allow them to get in a vulnerable situation. At the same time, the world has a just order where it gives everyone his or her right, everyone gets what they deserve; therefore, they will be rewarded for their effort within the five-years. It is because the finding of self-worth assumptions shows that they perceive themselves as good, ethical, and valuable, and that their self-esteem is high. The world is a safe place which has an order that gives value to good, ethical and valuable people. The finding obtained in the equality gender sub-dimension of GRAS in favor of the students who think that there will be a positive change in their lives, in the negative masculine sub-dimension of the EPAQ in favor of the students who think that there will be no change in their lives are consistent with the WAS and its sub-dimensions. GRAS equality gender sub-dimension bases the role descriptions of both sexual identities related to each other on equality, cooperation, respect and similar principles through democratic life values, independent of socio-cultural expectations [43]. Therefore, we can say that the individuals who think that there will be a positive change in their life within the next five years believe that they will realize this idea based on the definition of the equalitarian gender role. The significant difference in the negative masculine sub-dimension of EPAQ, in favor of the students who believe that there will be no change in the future makes us think that the negative role behaviors such as arrogance, selfishness, hostility, suspicion, dictatorship are related to the feeling of despair about the future [44]. When considered in terms of difference in WAS and its subdimensions in favor of the students who think that their future can change positively, it is thought that negative thinking about the future may also be associated with the negative 
WAS. The finding suggests that the personal attributes regarding gender identity behaviors of the students, who do not believe that there will be a positive change in their future, are not positive. Moreover, this result can be supported by the findings of psycho-social researches on anger, violence and aggression as well as researches on hope and hopelessness in the context of positive psychology and cognitive psychology $[45,46,47,48]$.

4.12. According to the situation of thinking a positive change will occur in their lives within 5 years with the education received in the positive femininity sub-dimension of EPAQ ( $\mathrm{Y} \bar{x}=29.07 / \mathrm{N} \bar{x}=27.20)$, GRAS total scores $(\mathrm{Y} \bar{x}=145.95 / \mathrm{N} \bar{x}=136.30)$, the equalitarian gender role sub-dimension of GRAS ( $\mathrm{Y} \bar{x}=33.74$ / N $\bar{x}=30,72)$, marriage gender role $(\mathrm{Y} \bar{x}=33.57 / \mathrm{N} \bar{x}=31.63)$, male gender role $(\mathrm{Y} \bar{x}=23.71 / \mathrm{N} \bar{x}=21.85)$; there is significant difference found in favor of those who think there will be difference in their lives with the education. We can say that the difference in the femininity dimension of EPAQ and its subdimensions equalitarian gender role, marriage gender role and male gender role in favor of the individuals who think that there will be a positive change in the way of life through education, shows that the students give importance to their positive role behaviors as individuals who are open to development as women and men [49,50].

4.13. According to the situation that additional trainings must be taken to change/improve life in the positive femininity sub-dimension of EPAQ ( $\mathrm{Y} \bar{x}=29.15$ / $\mathrm{N} \bar{x}=27.83$ ), total GRAS scores ( $\mathrm{Y} \bar{x}=146.30 / \mathrm{N} \bar{x}=139.84)$, female gender role ( $\mathrm{Y} \bar{x}=27.64$ $/ \mathrm{N} \bar{x}=25.50)$, traditional gender role $(\mathrm{Y} \bar{x}=27.88 / \mathrm{N} \bar{x}=26.22)$ sub-dimensions of GRAS, there is significant difference in favor of those who think trainings must be received. Regarding the EPAQ and GRAS, the significant difference about students who think they need to receive additional trainings makes us think that they give importance to empowerment of women. Moreover, the difference in positive femininity sub-dimension of EPAQ and the difference in the traditional gender role of GRAS of those who think it is necessary to receive training make us think that it is necessary for students to perceive change as a form of behavior required by positive femininity.

4.14. As a result of the correlation analyses, a positive correlation $(r=0.116)$ is observed between the assumptions related to world and personal attributes. Furthermore, the subdimensions of the characteristics that constitute the research theme are also related to each other in positive and negative aspects. According to the correlation analysis, in line with the correlation analysis between WAS and EPAQ, as the WAS score increases, difference in the EPAQ scores can be observed.

\section{Conclusion and recommendations}

According to the World Health Organization, the quality of life is the perception of the people's own life in a sociological system by their goals, expectations, standards and interests. The relevant literature however defines the quality of life based on the objective criteria related to the right to live, such as education, health, income, profession, physical environment etc. Both perspectives include people's experiences of life and information on how they may be affected by them. In this context, the study aimed to examine world assumptions, personal implications and social gender role behaviors in relation to perceptions of adolescents' own quality of life, taking objective criteria into account.

In the study, adolescents' perceptions of their quality of life were evaluated with the questions related to the "past, the period in which the research was conducted and the future". The education level and working status were also considered.

The results of the study show difference in terms of world assumptions, personal attributes and social role behaviors between the male and female students. It is observed that the mother's education level, and the working status of the father and mother cause a difference in world assumptions, personal attributes and social role behaviors of the students. 
Education and working status of parents provide information about the standards regarding the quality and quantity of the environment in which the child lives. Thus, the acquired information is thought to be important in terms of the studies towards adolescents.

Students' perceptions of the economic and social situations that may affect their lives were obtained with answers to the questions related to the last five years (including the process in which the research was conducted) and within the next five-year period. With these questions students' world assumptions, interpersonal implications and social gender roles in the context of past, present and the future were examined. With the questions in this context, difference was found between those who experienced a positive event (increase in life standard/income) and who experienced a negative event (economic crisis, dismissal of a family member); between those who think they live suitable to their expectancy of life with their family and who think the opposite; between those who do not think to change the current environment and are happy with their physical and social environment and who are not; and between those who think there might be a positive change in their lives within the next five years and who not; with respect to world assumptions, personal relations and social gender roles. The world assumptions of the students who answer to relevant questions positively (who has not experienced a crisis, are happy with their social environment, believe in positive changes in the future) are found positive with regards to the world assumptions, meaningfulness of the world, benevolence of world and self-worth. It is found that the students' relative results were distributed among dimensions of "Total scores of world assumptions and justice, control, self-worth, luck and benevolence of people"; and the results of the students who answered negatively were distributed more in the random dimension. The results of the positive responding students regarding their interpersonal attributes are related to their differences in positive masculine and positive femininity dimensions. Among the results of students who responded negatively, the difference in negative masculine, negative femininity (verbal) and negative femininity (relational) dimensions is remarkable. While the results of the traditional gender role highlight the female role expectations in the society; the students responding positively with regards to social gender roles, show difference in female gender role, male gender role and egalitarian gender role dimensions. Moreover, according to the correlation analysis carried out in the study, a low but positive correlation was found between the world assumptions scale scores and personal attributes.

As a conclusion, it has been found that the adolescents' perception of their quality of life in the context of "past, present and future" may differentiate their thoughts on world, life, themselves, and in this regard the definitions of gender identity and role behaviors in social relationship. In this sense, it is possible to say that the socio-economic experiences which adolescents experience with their families do not only remain for that period, but also create a change in definitions towards the future world and therefore their interpersonal attributes and the perceptions of gender roles may change. In addition; considering that the research features are related to many factors; it is important to repeat the related studies in a multidimensional way regarding the "adolescents".

\section{References}

1. Damian, R. I., \& Robins, R. W. (2012). Investigations into the human self: A naturalist perspective. Social Cognition, 30(4), 431-448.

2. Axelrod, R. (1973). Schema theory: An information processing model of perception and cognition. American Political Science Review, 67(4), 1248-1266.

3. Thompson, S. C., \& Janigian, A. S. (1988). Life schemes: A framework for understanding the search for meaning. Journal of Social and Clinical Psychology, 7(23), 260-280. 
4. Bratman, G. N., Hamilton, J. P., \& Daily, G. C. (2012). The impacts of nature experience on human cognitive function and mental health. Annals of the New York Academy of Sciences, 1249(1), 118-136.

5. Janoff-Bulman, R. (1989). The benefits of illusions, the threat of disillusionment, and the limitations of inaccuracy. Journal of Social and Clinical Psychology, 8(2), 158175 .

6. Mikulincer, M., Shaver, P. R., \& Pereg, D. (2003). Attachment theory and affect regulation: The dynamics, development, and cognitive consequences of attachmentrelated strategies. Motivation and Emotion, 27(2), 77-102.

7. Jeavons, S., \& Greenwood, K. M. (2007). World assumptions, coping and attributions. Personality and Individual Differences, 42(7), 1427-1437.

8. Janoff-Bulman, R., \& Schwartzberg, S. S. (1991). Toward a general model of personal change. Handbook of social and clinical psychology: The health Perspective, 488508 .

9. Janoff-Bulman, R. (2010). Shattered assumptions. USA: The Free Press.

10. Lilly, M. M., Valdez, C. E., \& Graham-Bermann, S. A. (2011). The mediating effect of world assumptions on the relationship between trauma exposure and depression. Journal of Interpersonal Violence, 26(12), 2499-2516.

11. Maschi, T., Macmillan, T., Morgen, K., Gibson, S., \& Stimmel, M. (2010). Trauma, world assumptions, and coping resources among youthful offenders: Social work, mental health, and criminal justice implications. Child and Adolescent Social Work Journal, 27(6), 377-393.

12. Dekel, R., Solomon, Z., Elklit, A., \& Ginzburg, K. (2004). World assumptions and combat-related posttraumatic stress disorder. The Journal of Social Psychology, 144(4), 407-420.

13. Steinberg, L., \& Morris, A. S. (2001). Adolescent development. Annual Review of Psychology, 52(1), 83-110.

14. Susman, E. And Alan Rogal . (2004). Puberty and Psychological Development. Richard M. Lerner and Laurence Steinberg (ed.)( (15-45). Handbook of Adolescent Psychologhy (second Edition) New Jersey: John Wiley\&Sons, Inc.

15. Marcia, J. E. (1966). Development and validation of ego-identity status. Journal of Personality andSsocial Psychology, 3(5), 551.

16. Rose, A. J., \& Rudolph, K. D. (2006). A review of sex differences in peer relationship processes: potential trade-offs for the emotional and behavioral development of girls and boys. Psychological Bulletin, 132(1), 98.

17. Bem, S. L. (1981). Gender schema theory: A cognitive account of sex typing. Psychological Review, 88(4), 354.

18. Arnett, J. J. (2007). Suffering, selfish, slackers? Myths and reality about emerging adults. Journal of Youth and Adolescence, 36(1), 23-29.

19. Lilly, M. M., Howell, K. H., \& Graham-Bermann, S. (2015). World assumptions, religiosity, and PTSD in survivors of intimate partner violence. Violence Against Women, 21(1), 87-104.

20. Elklit, A., Shevlin, M., Solomon, Z., \& Dekel, R. (2007). Factor structure and concurrent validity of the world assumptions scale. Journal of Traumatic Stress: Official Publication of The International Society for Traumatic Stress Studies, 20(3), 291-301.

21. Butler, T., Giordano, S., \& Neren, S. (1985). Gender and sex-role attributes as predictors of utilization of natural support systems during personal stress events. Sex Roles, 13(9-10), 515-524. 
22. WHOQOL GROUP. (1995). The World Health Organization quality of life assessment (WHOQOL): position paper from the World Health Organization. Social science \& medicine, 41(10), 1403-1409.

23. Hofstede, G. (1984). The cultural relativity of the quality of life concept. Academy of Management Review, 9(3), 389-398.

24. Wallander, J. L., Schmitt, M., \& Koot, H. M. (2001). Quality of life measurement in children and adolescents: issues, instruments, and applications. Journal of Clinical Psychology, 57(4), 571-585.

25. Topolski, T. D., Patrick, D. L., Edwards, T. C., Huebner, C. E., Connell, F. A., \& Mount, K. K. (2001). Quality of life and health-risk behaviors among adolescents. Journal of Adolescent Health, 29(6), 426-435.

26. Yilmaz, B. (2008). Dunyaya Iliskin varsayimlar Olcegi gecerlik ve guvenirlik calismasi: On calisma [Reliability and validity study of World Assumptions Scale: Pilot study]. Turk Psikoloji Yazilari, 11(21), 41-51.

27. Demirtaş-Madran, H. A. (2016). Genişletilmiş Kişisel Yüklemeler Ölçeğinin Türkçe formunun geçerlilik ve güvenilirlik çalışması. Anatolian Journal of Psychiatry/Anadolu Psikiyatri Dergisi, 17.

28. Zeyneloğlu, S., \& Terzioğlu, F. (2011). Toplumsal cinsiyet rolleri tutum ölçeğinin geliştirilmesi ve psikometrik özellikleri. Hacettepe Üniversitesi Eğitim Fakültesi Dergisi, 40, 409-420.

29. Gebauer, M. (2017). The role of world assumptions in the development of PTSD: Cultural differences between western and non-western respondents (Bachelor's thesis, University of Twente).

30. Helmreich, R. L., Spence, J. T., \& Wilhelm, J. A. (1981). A psychometric analysis of the Personal Attributes Questionnaire. Sex Roles, 7(11), 1097-1108.

31. Demirtaş-Madran, H. A. (2016). Genişletilmiş Kişisel Yüklemeler Ölçeğinin Türkçe formunun geçerlilik ve güvenilirlik çalışması. Anatolian Journal of Psychiatry/Anadolu Psikiyatri Dergisi, 17(Supplement 1), 60-68.

32. Esen, E., Siyez, D., Soylu, Y., \& Demirgürz, G. (2017). Üniversite öğrencilerinde toplumsal cinsiyet algısının toplumsal cinsiyet rolü ve cinsiyet değişkenlerine göre incelenmesi//Examination of gender perception of university students according to sex and sex roles. e-International Journal of Educational Research, $8(1)$.

33. Collins, W. A. and Brett Laurse. (2004). Parent-adolescent relationships and influences. Richard M. Lerner and Laurence Steinberg (ed.) (331-361). Handbook of Adolescent Psychologhy (second Edition) New Jersey: John Wiley\&Sons, Inc

34. Yüksel, Ö. (2013). Kadınlarda evlilik uyumu ve psikolojik belirtiler arasındaki ilişki: Stresle baş etme biçimleri ve toplumsal cinsiyet rolü tutumlarının aracı rolleri. (Yayımlanmamış doktora tezi/yüksek lisans tezi). Hacettepe Üniversitesi. Ankara.

35. Kurt, Ş. (2006). İşsizliğin psiko-sosyal sonuçları ve Türkiye üzerine muhtemel etkileri. Sosyal Siyaset Konferanslar Dergisi, (51), 357-379.

36. Çelik, A. S., Pasinlioğlu, T., Gonca, T. A. N., \& Koyuncu, H. (2013). Üniversite öğrencilerinin cinsiyet eşitliği tutumlarinin belirlenmesi. Florence Nightingale Hemşirelik Dergisi, 21(3), 181-186.

37. Yilmaz, B. (2008). Dünyaya iliskin varsayımlar ölçeği geçerlik ve güvenirlik çalışması: Ön çalışma: [Reliability and validity study of World Assumptions Scale: Pilot study]. Türk Psikoloji Yazılart, 11(21), 41-51.

38. Sümer, N., Solak, N., \& Harma, M. (2013). Işssiz yaşam: İsssizliğin ve iş güvencesizliğinin birey ve aile üzerindeki etkileri. Koç Üniversitesi Yayınları.

39. Özmen, S. K. (2004). Aile içinde öfke ve saldırganlığın yansımaları. Ankara Üniversitesi Eğitim Bilimleri Fakültesi Dergisi, 37(2), 27-39. 
40. Kurt, Ş. (2006). İşsizliğin psiko-sosyal sonuçları ve Türkiye üzerine muhtemel etkileri. Sosyal Siyaset Konferansları Dergisi, (51), 357-379.

41. Can, Y. (2014). Türk ailesinde aile içi şiddetin kültürel dinamikleri. Electronic Turkish Studies, 9(8). 13-19.

42. Karakaya, Handan. Algis1, Toplumsal cinsiyet algıs1, din ve kadın. Journal of Analytic Divinity, (2)2, 36-62.

43. Gebauer, M. (2017). The role of world assumptions in the development of PTSD: Cultural differences between western and non-western respondents (Bachelor's thesis, University of Twente).

44. Eisler, R. M., Skidmore, J. R., \& Ward, C. H. (1988). Masculine gender-role stress: Predictor of anger, anxiety, and health-risk behaviors. Journal of Personality Assessment, 52(1), 133-141.

45. Eryılmaz, A. (2011). Ergen öznel iyi oluşu ile olumlu gelecek beklentisi arasındaki ilişkinin incelenmesi. Dusunen Adam: Journal of Psychiatry \& Neurological Sciences, 24(3). 209-215.

46. Tümkaya, S., Aybek, B., \& Çelik, M. (2010). Yoksul ailelerden gelen ergenlerde psiko-sosyal bir olgu olarak umutsuzluk ve boyun eğici davranışların incelenmesi. Uluslararası İnsan Bilimleri Dergisi, 7(1), 970-984.

47. Uluçay, T., Özpolat, A. R., İşgör, İ. Y., \& Taşkesen, O. (2014). Lise öğrencilerinin gelecek beklentileri üzerine bir araştırma. Education Sciences, 9(2), 234-247.

48. Brems, C., \& Johnson, M. E. (1989). Problem-solving appraisal and coping style: The influence of sex-role orientation and gender. The Journal of Psychology, 123(2), 187194.

49. Özaydınlık, K. (2014). Toplumsal cinsiyet temelinde Türkiye'de kadın ve eğitim. Sosyal Politika Çalışmaları Dergisi, (33). 93-112.

50. Prentice, D. A., \& Carranza, E. (2002). What women and men should be, shouldn't be, are allowed to be, and don't have to be: The contents of prescriptive gender stereotypes. Psychology of women quarterly, 26(4), 269-281. 